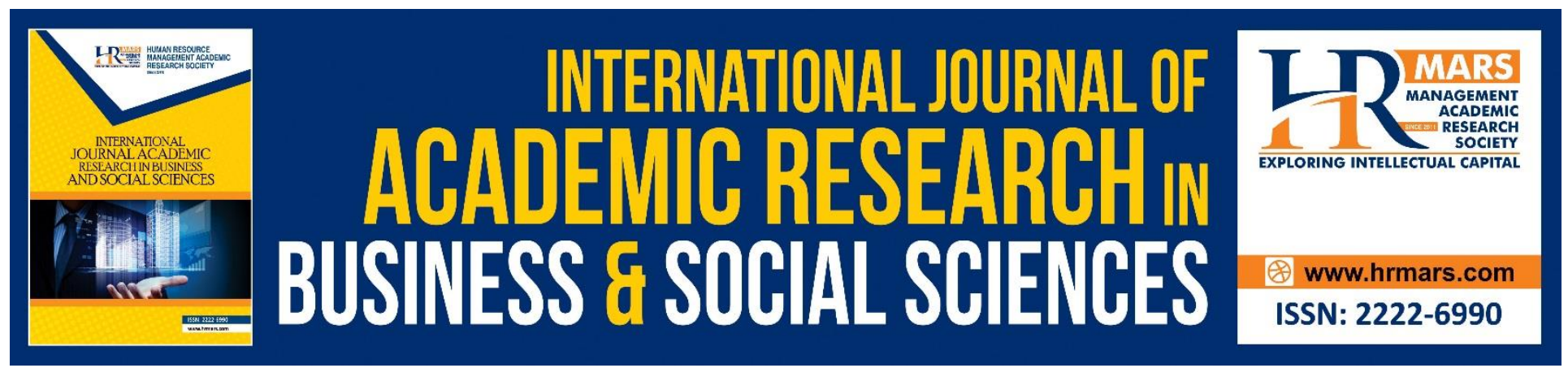

\title{
Enhancing the Influence of Sustainable Supply Chain Management on Manufacturing Firm Performance through Organizational Innovation
}

Kwame Asamoah, Devika Nadarajah

To Link this Article: http://dx.doi.org/10.6007/IJARBSS/v10-i8/7501

DOI:10.6007/IJARBSS/v10-i8/7501

Received: 02 May 2020, Revised: 09 June 2020, Accepted: 24 July 2020

Published Online: 16 August 2020

In-Text Citation: (Asamoah, Nadarajah, 2020)

To Cite this Article: Asamoah, K., Nadarajah, D. (2020). Enhancing the Influence of Sustainable Supply Chain Management on Manufacturing Firm Performance through Organizational Innovation. International Journal of Academic Research in Business and Social Sciences. 10(8), 59-74.

Copyright: (c) 2020 The Author(s)

Published by Human Resource Management Academic Research Society (www.hrmars.com)

This article is published under the Creative Commons Attribution (CC BY 4.0) license. Anyone may reproduce, distribute, translate and create derivative works of this article (for both commercial and non-commercial purposes), subject to full attribution to the original publication and authors. The full terms of this license may be seen at: $\underline{\text { http://creativecommons.org/licences/by/4.0/legalcode }}$

Vol. 10, No. 8, 2020, Pg. $59-74$

Full Terms \& Conditions of access and use can be found at http://hrmars.com/index.php/pages/detail/publication-ethics 


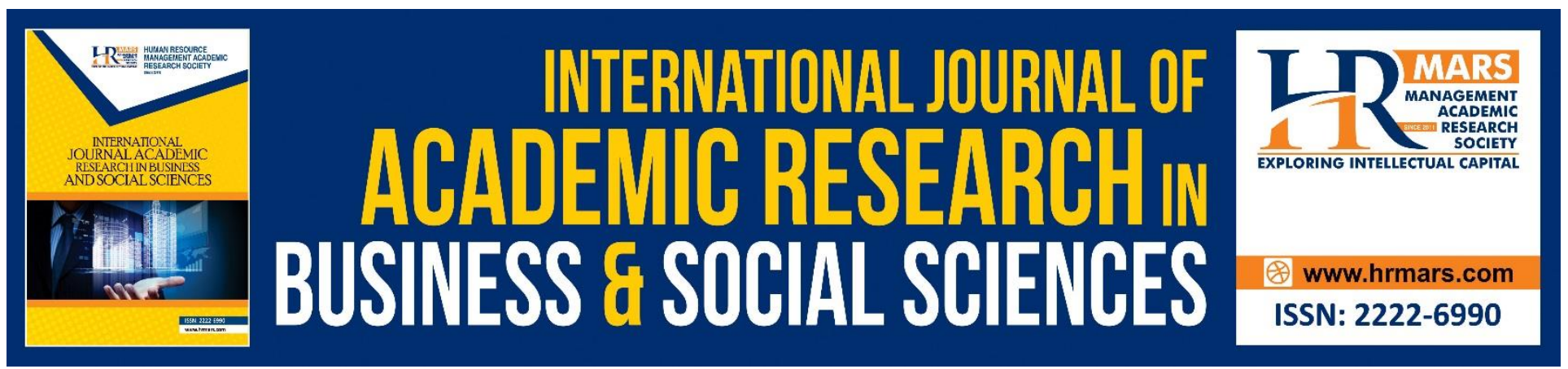

\title{
Enhancing the Influence of Sustainable Supply Chain Management on Manufacturing Firm Performance through Organizational Innovation
}

\author{
Kwame Asamoah ${ }^{1}$, Devika Nadarajah² \\ ${ }^{1}$ Putra Business School, University Putra Malaysia, Serdang, Selangor Darul Ehsan, Malaysia. \\ ${ }^{2}$ Putra Business School, Level 4 Office Building of The Deputy Vice Chancellor (Research and \\ Innovation), Universiti Putra Malaysia, 43400 Serdang, Selangor, Malaysia.
}

\begin{abstract}
Purpose: The worsening case of global warming and the beleaguered eco-system have necessitated a compelling need for manufacturing organisations to embed sustainable supply chain management practices into their operations and deploy cutting-edge innovative initiatives to salvage the environment and the health of mankind. This paper is purposed to extend and strengthen theorybuilding on sustainable supply chain management (SSCM) concept and innovation to foster improved operational performance based on institutional theory.
\end{abstract}

Design/Methodology/Approach: The study is designed to test the proposition that pressure from external institutions impels organisations engaged in sustainable supply chain management practices to adopt state-of-the-art innovative practices as a tool to resolving inherent challenges in order to improve operational performance. The study therefore employs a model that makes practical utilisation of organisational innovation, underpinned by institutional theory to accentuate the predictive potential of the Triple Bottom Line on firm performance.

Findings: Empirical findings indicate that sustainable supply chain management practices have positive correlation with operational performance. However, contrary findings exist that reveal that the relationship is weak when construed as direct. This justifies the introduction of innovation into the SSCM-performance model aimed at amplifying the predictive potential of the concept on operational performance goals.

Originality/Value: The study introduces a robust and comprehensive model that exploits three overarching sustainability concepts that generate far-reaching implications for researchers as well as industry practitioners. These concepts have scarcely been studied as a holistic integrated model. The examination of the mediating effects of organisational innovation in the Sustainable Supply Chain Management-Operational Performance link offers a novel theoretical contribution to the SSCM literature and is expected to serve as a roadmap for successful implementation of future sustainability initiatives by firms. 
INTERNATIONAL JOURNAL OF ACADEMIC RESEARCH IN BUSINESS AND SOCIAL SCIENCES

Vol. 10, No. 8, August, 2020, E-ISSN: 2222-6990 @ 2020 HRMARS

Keywords: Sustainable Supply Chain Management, Manufacturing, Organisational Innovation, Institutional Theory.

\section{Introduction}

The sustainability literature is replete with findings that suggest that the relationship between Sustainable Supply Chain Management practices (environmental, social and economic) and Operational Performance is indirect and this has generated mounting calls from authors and practitioners alike for future researchers to identify and introduce plausible intervening variables that may help improve the predictive potential of the TBL dimensions on operational performance (Das, 2018; Cheu et al., 2017). In spite of the many attempts by researchers in that regard, the mediating role of organisational innovation has been scarcely considered in that effort. This research gap constitutes justifiable basis for this conceptual paper which, among others, proposes a robust and comprehensive model that integrates the TBL dimensions, organisational innovation and Operational Performance.

Underpinned by Institutional Theory, the suggested model offers a comprehensive examination of the direct and indirect effects of SSCM dimensions on Operational Performance through organisational innovation within the context of sustainability. The integrated framework is the product of a thorough review of the sustainability literature which considers organisational innovation as a potential driver capable of amplifying the predictive power of environmental, social and economic practices on Operational Performance. The outcome of this study is the development of verifiable propositions which lend themselves to future empirical investigations.

\section{Literature Review \\ Operational Performance}

Saleh (2017) defines operational performance as the performance related to organizations' internal operations, such as productivity, product quality and customer satisfaction. A very comprehensive analysis of operational performance is attributed to the seminal work by Samson and Terziovski (1999) who explained, inter alia, that operational performance, in relation to manufacturing operations, can be construed from two overarching perspectives; quality performance and inventory management performance perspectives with each having unique sub-categories. Quality performance is viewed to include improved product/service quality, increased productivity, reduced costs of defects and rework whilst inventory management performance, according to them, encapsulates performance metrics such as purchase material turnover, total inventory turnover, and reduced inventory obsolescence costs. Baird et al. (2011) expanded these metrics to include customer satisfaction dimensions such as reduced delivery lead time of finished products/services to customers, reduced customer complaints, improved customer satisfaction level and a decline in the number of warranty claims.

According to Tortorella et al. (2019), a myriad of researchers utilize operational performance as proxy for financial performance because of the difficulty associated with accessing financial information from organistaions due, in part, to the fact that it is regarded as vital and privileged information and which is jealously protected and kept within the confines of senior level managers. Additionally, improvements in operational performance are generally visible and can be easily perceived by wider range of respondents including senior and middle level management alike, and this makes for easy 
INTERNATIONAL JOURNAL OF ACADEMIC RESEARCH IN BUSINESS AND SOCIAL SCIENCES Vol. 10, No. 8, August, 2020, E-ISSN: 2222-6990 @ 2020 HRMARS

conduct of survey ( see Tortorella and Fettermann, 2018; Rossini et al., 2019) Since SSCM practices impinge on a wide facets of performance metrics, this study intends to measure operational performance by process-related indicators as suggested by Das (2018): improvement in the efficiency of inbound and outbound logistics as well as decrease in the cost of production.

Neely et al. (2002) also submit that performance measurement constitutes a critical enterprise for organisations since majority of them lack a systematic and robust process with defined parameters for evaluation and control even though they appreciate its importance in their scheme of operations. They further explain that performance is a parameter used to quantify the "efficiency and/or effectiveness of a past action" and "the organization's ability to achieve its objectives, by using its resources efficiently" (Daft \& Marcic, 2004).

Dam et al. (2014) re-enforce the above stance by positing that firms still consider performance measurement as a contentious issue despite the recognition of its important role in the efficient and effective management of organizations. A further observation was made by the researchers to the effect that few organizations appear to have systematic processes to manage the evolution of their performance measurement systems, and few researchers seem to have explored the issue." (Kennerley and Neely, 2002)

More importantly, Villas-Bôas, (2011); Callado, (2010) submit that in order to evaluate performance in relation to business, defining the parameters that the company will use represents the first critical step in deconstructing the variable. For instance, it is of utmost importance, they argue, to properly delineate the appropriate instruments that help to measure business performance, composed of one or more variables that reveal wider meanings of the phenomena to which they refer, allowing the monitoring of the firm's interests and the planning of actions to improve performance.

Dam et al. (2014) further observe that past studies have widely utilised financial measures to evaluate the performance of organizations, but since the 1980s, due to the increasing complexity of the markets where organizations compete, there is a growing perception that it is no longer appropriate to use financial measures as the only criterion to evaluate business success (Kennerley \& Neely, 2002). Therefore, in a true and proper sense, a series of performance measures is necessary, so that organizations can appropriately assess their organizational results and provide parameters for decision-making.

It is in line with the above that this study adopts operational performance, which is normally used interchangeably with production performance to indicate production flexibility (volume), production and speed of delivery, production Cost, quality and conformity etc. This is because, findings in literature suggest that analytical and empirical studies relating to the subject are still limited, both in quantity as well as in-depth analysis (Dam et al., 2014).

\section{Triple Bottom Line (TBL)}

The provenance of the TBL concept, according to Kavigtha (2017), can be traced to the formative work by Elkington (2004) which was later extended and given prominence by Kleindorfer et al (2005). TBL framework advances the goal of sustainability in business practices, in which companies look 
INTERNATIONAL JOURNAL OF ACADEMIC RESEARCH IN BUSINESS AND SOCIAL SCIENCES Vol. 10, No. 8, August, 2020, E-ISSN: 2222-6990 @ 2020 HRMARS

beyond profits to include social and environmental issues to measure the full cost of doing business (Investopedia, 2019).

Additionally, Elkington defined the concept to include the assessment of overall business performance based on three important areas: economic (profit), social (people) and environmental (planet). This concept is sometimes referred to as 'sustainability' which has become, in many respects, a reference point of research in the domain of sustainability in view of the fact that TBL attempts to treat all three dimensions of sustainability with equal importance. Both the concepts of TBL and sectoral view of the model served as triggers for the development of SSCM framework (Carter and Rogers, 2008; Carter and Easton, 2011; Winter and Knemeyer, 2013).

The concept 'Sustainability' could be explained to mean delivering the current needs of the society while conserving the same ability of future generations and this lies at the heart of sustainability management (WCED, 1987, p.45). This includes management of organizational products, services and processes across their supply chains and life cycles against the multi-dimensional criteria of triple bottom-line (TBL) i.e. economic, ecologic and social. Stemming from this societal and industrial challenge, sustainability management research is growing to foster innovative management approaches, synergistic strategies and integrated decision-making tools for comprehensive development of economic, ecologic and social sustainability (Bastas and Liyanage, 2018).

Researchers such as Pazirandeh and Jafari (2013) posit that sustainability measurements integrating social, environmental and economic dimensions are uncommon in the literature. They further explain that studies pertaining to sustainable supply chain management have either focused on environmental dimensions or the social dimension. The integrated management concept of SSCM was articulated by Seuring and Müller (2008) as: "the management of material, information and capital flows as well as collaboration among firms along the supply chain while taking goals from all three dimensions of sustainable development, i.e., economic, environmental and social, into account which are derived from custom errand stakeholder requirements".

Economic criteria include indicators of traditional operational performance, such as cost, quality, flexibility and delivery, as well as measures of market and financial performance (profitability, sales growth, and market share). Yang (2013) echoes the point that fulfilling economic performance goals remains a firms' dominant objective because, without meeting high standards of operational and business priorities in a highly competitive marketplace, their survival is hardly guaranteed.

On the other hand, Das (2018) explain the environmental criteria to encapsulate the minimisation of the negative impact of environmental wastes and risks and improvement in the efficiency of consuming resources in terms of wastes, products, and energy. Kavigtha (2017) opine that firms that intend to be environmentally friendly need to achieve two outcomes: innovation of their facilities to realize a high level of resource efficiency and reduction of negative environmental pollutants. Such endeavours, he explains, will help the focal firms conform to societal demands of sustainability and to satisfy environmentally-conscious customers. Thus, the overwhelming pre-occupation of contemporary business managers is, primarily, to improve the environmental aspects of their company.

Social criteria are grounded in corporate social responsibility (CSR), which highlights an organization's public acts of good citizenship. The literature, according to Das (2018), suggests two aspects of social 
INTERNATIONAL JOURNAL OF ACADEMIC RESEARCH IN BUSINESS AND SOCIAL SCIENCES Vol. 10, No. 8, August, 2020, E-ISSN: 2222-6990 @ 2020 HRMARS

performance: an internal aspect, also referred to as Socially-inclusive Practices for Employees (SPE) and an external aspect also referred to as Socially-inclusive Practices for Community (SPC).

SPE relates to employee well-being and equity such as provision for fair wages and perquisites; safe, healthy, and positive working environment; health care benefits; leave and other fringe benefits; and opportunities for growth and advancement (Welford and Frost, 2006; Hutchins and Sutherland, 2008; Lu et al., 2012; Marshall et al., 2014; Mani et al., 2016a, 2016b; Zhu et al., 2016).

Conversely, SPC relates to community performance indicators, such as corporate philanthropic commitment or investments made by a firm in creating opportunities for the surrounding community in terms of generation of employment and business and also in providing education, training, and healthcare facilities with a view to projecting the firm as progressive in the eyes of the stakeholders (Hutchins and Sutherland, 2008; Lu et al., 2012; Mani et al., 2016a, 2016b; Zhu et al., 2016).

In the final analysis, Mittra and Datta (2014) endorses the argument put forward by Das (2018) to the effect that the simultaneous consideration of economic, environmental, and social priorities can provide firms with a competitive advantage and consequently enable them to edge out competitors in winning target customers.

\section{Organisational Innovation}

According to Mortensen and Bloch (2005), the term organizational innovation or innovation in organization is defined in the Oslo Manual $^{1}$ to encapsulate new idea implementation for product improvement and new organizational process or method that applies in organizations, groups, workplaces, and operations (see also Waheed, 2019). Baregeh et al. (2009) explain that organizational innovation is mainly centered on four activities namely new product development, new production process, creative strategy, and economic organization.

The development of innovative concept in SSCM can be traced to the seminal work by Thompson (1965) who explained innovation as the generation, acceptance and implementation of new ideas, processes, products or services. This formative work by Thompson was given impetus by Gualandris and Kalchschmidt (2014), who argue, inter alia, that innovativeness relates to a company's willingness or ability to change processes, products and management systems, mainly through architectural or radical innovation and that the concept has witnessed massive citation in the literature on sustainability (Christmann, 2000; Klassen and Vereecke, 2012, Nidumolu et al., 2009; Pagell and Wu, 2009; Porter and Van der Linde, 1995; Wu and Pagell, 2011). Porter and Van der Linde (1995) sought to illuminate the concept by suggesting that "ignorance" and "a static mind-set" prevent companies from having a firm grasp of the fact that environmental (and social) performance can be significantly improved while reducing costs, thus constraining the development of SSCM practices. The implication here is that firms that adopt innovativeness as a key business strategy can reduce the trade-off between cost and SSCM adoption whiles significantly improving profitability in the medium to long term. Thus, innovative thinking can be regarded as an enabling tool key to addressing sustainabilityrelated challenges confronting organisations globally (Gualandris and Kalchschmidt 2014). In the considered view of Gualandris \& Kalchschmidt (2014), this compelling evidence imposes on

${ }^{1}$ OECD document on "the Measurement of Scientific and Technological Activities, Proposed Guidelines for Collecting and Interpreting Technological Innovation Data" which contains guidelines for collecting and using data on industrial innovation. 
INTERNATIONAL JOURNAL OF ACADEMIC RESEARCH IN BUSINESS AND SOCIAL SCIENCES

Vol. 10, No. 8, August, 2020, E-ISSN: 2222-6990 @ 2020 HRMARS

researchers a bigger responsibility to further carry out empirical investigation into the relationship between innovativeness and sustainability and on the role of the former in shaping organizational responses to social and environmental pressure.

\section{Environmental Management Practices, Organisational Innovation and Operational Performance}

Literature is inundated with varying perspectives by scholars to the effect that environmental and social initiatives are costly undertakings. For example, Walley and Whitehead (1994) state that, "Responding to environmental challenges has always been a costly and complicated proposition for managers," and as a result, "win-win situations are very rare and will likely be overshadowed by the total cost of a company's environmental program."

The above view is endorsed by Ahmed et al. (2019) who observe that companies, by their very design and objectives, are, more often than not, preoccupied with inordinate desire to make profit to the total neglect of the environment and the health and development of communities. The key argument here is that adoption of environmental sustainability initiatives have significant financial disadvantages because of the huge financial outlay that must be sunk into such investment at the incipient stage. For instance, Dam and Petkova (2013) observe that firms that decide to pursue environmental sustainability would have to commit enormous amount of money in new or modified products and processes such as product redesign, training of employees, acquisition of environmentally friendly machines, increased operational costs as environmentally friendly production may call for higher safety standards and more control.

Such prohibitive costs that accompany the adoption of environmental sustainability initiatives have forced researchers such as Bag et al. (2018) to call into question the relevance, feasibility and economic viability of such initiatives by asking whether such initiatives are worth pursuing. In fact, researchers such as Dam and Petkova (2013) observe that not all firms seem convinced that environmental sustainability leads to better financial performance.

In contrast, stakeholders are also concerned about the devastating consequences of manufacturing operations world-wide such as pollution, carbon emissions etc. Against this backdrop, Kneipp et al. (2019) report that companies have realized the importance of adopting sustainable innovation practices in order to minimize negative social and environmental impacts that result from their activities and, consequently, achieve superior corporate performance. This is because, in most jurisdictions, legislation and the society itself impel organisations to carry out sustainable development in tandem with innovation in products, services, processes and business models since a mere adoption of sustainable initiatives does not, necessarily, lead to superior performance by firms.

This view is accentuated by authors such as Dyck and Silvestre (2018) and Dam and Petkova (2013) who observe that firms tend to subdue the adverse economic consequences of environmental management initiatives when they incorporate innovative practices into their operations in order to reduce the consumption of resources and decrease environmental pollution and this constitutes ample testimony of the mediating role innovation plays in the relationship between EMP and operational performance. For instance, Bocken et al. (2014) posit that successful companies strategically reconcile sustainability with innovation as a sure way of achieving competitive advantage, because it enables firms to redefine products, technologies, processes and business models. 
INTERNATIONAL JOURNAL OF ACADEMIC RESEARCH IN BUSINESS AND SOCIAL SCIENCES Vol. 10, No. 8, August, 2020, E-ISSN: 2222-6990 @ 2020 HRMARS

Aguilera-Caracuel \& Ortiz-de-Mandojana (2013) wind up with interesting view that suggests that when organisations embed innovative practices into their environmental management systems, it is likely to engender technological improvements which will lead to energy saving, pollution minimization, waste recycling, green product development and corporate environmental management. However, Kneipp et al. (2019) posit, to the contrary, that even though EMP has the potential to bring about improved firm performance, the effect can only be felt in the long-run due to huge initial capital outlay and that companies must create the necessary conditions to enhance performance. In spite of the crucial role innovation plays in the EMP-firm performance link, Kneipp et al. (2019) conclude that studies that address the impact of the adoption of innovation practices on environmental management practices and operational performance are still incipient.

\section{Social Practices, Organisational Innovation and Operational Performance}

Hult et al. (2004) opine that contemporary organisations, having fuller appreciation of the crucial role of innovation in their scheme of operations, have taken the initiative to embed innovativeness internally by encouraging employees, teams and executives to exploit new behaviours, products, services and practices. The underlying rational for this effort hinges on the conviction that when employees are equipped to be able to generate and fully utilise new knowledge and information obtained from channel partners such as suppliers, customers and other key stakeholders, innovation can facilitate knowledge development and diffusion throughout organisations and supply chains. In effect, Innovation capabilities facilitate knowledge expansion via the effective use of supply chain relationships to improve on firm performance. In particular, when employees, through constant training and re-training, attain the requisite skill-set and learn new and better ways of doing things, they are able to improve on the quality of products they churn out, quickly respond to customer orders, deploy state-of-the-art inventory management practices, better manage collaborative operations, and significantly enhance their throughput.

Bag (2018) also echoes the importance of innovation in organisational operations by positing that when organisations embed innovation and integrate it in their internal operations, it can engender positive working environment for employees with the added advantage of improving their well-being. Additionally, technologically-savvy organisations are able to significantly expand their businesses through economies of scale and create golden opportunities for the surrounding communities by way of employment generation as well as provision of education and health care facilities. Thus, innovative compliant organisations are able to improve their corporate social responsibility initiatives through improvement in profitability and operational performance.

Again, when organisations embed technology and innovations into their SSCM practices, it empowers them to significantly reduce the expenditure on health and safety of employees and lower recruitment and labour turnover costs resulting from safer warehousing and transportation and better working conditions. This view is eloquently echoed by Bag (2018) who theorises that lower labour costs and improved working conditions, generally, tend to increase employee motivation and productivity, and significantly lower absenteeism of supply chain personnel. In sum, literature suggests that a highly motivated employees will be in a better position to serve customers better, improve the quality of their products and thereby, in significant terms, reduce per unit cost of production which will bring about improvement in operational performance (Porteous et al., 2015; Toffel et al., 2015; Bag, 2018). 
INTERNATIONAL JOURNAL OF ACADEMIC RESEARCH IN BUSINESS AND SOCIAL SCIENCES Vol. 10, No. 8, August, 2020, E-ISSN: 2222-6990 @ 2020 HRMARS

\section{Economic Practices, Organisational Innovation and Operational Performance}

Carter (2005) submits that innovative companies that commit to waste reduction practices will experience strong positive influence on operational performance through reduced operating costs. This argument is given impetus by researchers such as Bag et al. (2018) who recognise the mediating role of innovation when they revealed in their study that application of cutting-edge innovative practices right across the primary activities of a firm's value chain ensures that managers are clothed with the requisite skill and technique to appropriately manage economic practices in relation to inbound and outbound logistics activities such as packaging use and disposal, warehouse safety and transportation impacts such as emissions, energy use, hazardous materials and worker safety and human rights, after-sales service concerns in the area of reversed logistics as well as environmentallysound disposal and disposition which eventually lead to a drastic reduction in the firm's operations costs and by extension, performance (Porter and Kramer, 2006). They conclude that technology development is sine qua non to improving supporting activities within the supply chain and which eventually translate into sustained SSCM performance and hence operational performance.

Additionally, Roy et al. (2004) observed that innovation generation may culminate into the transformation in products, services and processes, which decreases costs, enhances efficiency and, in turn, increase customer satisfaction. Innovation also leads to Cost savings through reduction in packaging waste (Mollenkopf et al., 2005; Rosenau et al., 1996), as well as the ability to design for reuse and disassembly (Christmann, 2000; Hart, 1995; Shrivastava, 1995c).

Carter (2005) posit that innovative companies that commit to waste reduction practices will experience strong positive influence on operational performance through reduced operating costs

\section{Institutional Theory as the Underpinning Theory}

Institutional theorists assert that institutions create institutional pressures which are "social, legal, and cultural forces" and such forces set cultural, legal and moral boundaries for actors (organisations) to operate. Organisations naturally respond to these pressures in order to appear legitimate and adopt appropriate policies that are socially accepted (Carpenter and Feroz, 2001). Legitimacy assures future survival through better access to scarce resources, which, in turn, results in tangible benefits like improved firm performance (Shubham et al., 2018) and intangible benefits like strong reputation (Staw and Epstein, 2000). According to Dimaggio and Powell (1983), the isomorphism of organizational structure and processes finds expression under three types of institutional pressures: normative, coercive and mimetic pressures.

Normative Isomorphism borders on the logic of propriety exhibited by bodies such as trade unions, certificated bodies etc. whilst they institute various codes of conduct that are regarded as decent and proper for the industry to conform (Grewal and Dharwardkar, 2002). Coercive pressures, on the other hand, emanate from other organizations on which a firm is dependent which may be either critical sources of organizational resources or governments with legislative power (Again, DiMaggio and Powell, 1983). Last but not least, mimetic isomorphism is, technically, a hedge against uncertainty in industry which arises out of a situation where there is no clear course of action for an organisation and which then necessitate that it becomes prudent and safer for the firm to imitate others' behaviours (DiMaggio and Powell, 1983). Mimicking can occur through direct contacts or by choosing 
INTERNATIONAL JOURNAL OF ACADEMIC RESEARCH IN BUSINESS AND SOCIAL SCIENCES

Vol. 10, No. 8, August, 2020, E-ISSN: 2222-6990 @ 2020 HRMARS

organizations with structural similarity despite no direct ties (Hayagreeva and Sivakumar, 1999; Perez-Aleman, 2011).

\section{The Effect of Intuitional Theory on Innovation and SSCM Adoption}

Ahmed et al. (2019) glean from a preponderance of findings in literature that suggest, in substance, that institutional pressures, in particular coercive pressures, play a moderating influence in the relationship between innovation and sustainable supply chain management adoption. They explain that whenever government authorities and institutions pressurize firms to minimize pollution levels emanating from their operations, it galvanises the affected organisations to ramp up their level of innovations by way of new product developments, usage of eco-friendly raw material and application of eco-friendly technology which ultimately minimizes the carbon footprint.

According to Jia et al. (2017), when government regulations, incessant pressures from civil society organisations and NGOs as well as stiff market competitions impel organisations to embed technology and innovation into their SSCM practices, it enables them to significantly reduce the expenditure on health and safety of employees and lower recruitment and labour turnover costs resulting from safer warehousing and transportation and better working conditions. This view is eloquently echoed by Bas (2019) who theorises that lower labour costs and improved working conditions, generally, tend to increase employee motivation and productivity, and significantly lower absenteeism of supply chain personnel.

In a similar vein, Jajja et al. (2018) opine that coercive pressures emanating from various actors may exact social compliance or compel the dependent organization to adopt social practices for improvement in operational performance and legitimacy. That is, the higher the presence of coercive power in the operational jurisdiction of focal organisations, the greater their compliance level in terms of environmental, social and economic initiatives. The opposite is true!

\section{Discussion}

Das (2018) and Cheu et al. (2017) have variously argued, based on empirical findings, that the relationship between sustainable supply chain management practice and operational performance is non-linear and will require some intervening variable to amplify the desired impact. In their view, this interesting finding warrants further investigation. This study draws inspiration from the finding and recommendation by the afore-mentioned authors and introduces organisational innovation as a mediator to accentuate the power of the Triple Bottom Line to correctly predict operational performance. The introduction of the mediating variable is meant to generate far-reaching implications for researchers and industry practitioners as well as regulatory bodies in respect of their decisions on sustainability matters. Again, the examination of the mediating effects of organisational innovation in the Sustainable Supply Chain Management-Operational Performance link is regarded as one of the novel attempts in the sustainability literature and is expected to serve as a roadmap for successful implementation of sustainability initiatives.

For instance, previous literature had indicated a direct relationship between the environmental, economic and social practices and operational performance. According Cheu et al. (2017), there exists an overwhelming argument in the sustainability literature which leans towards the fact that firms with a significant environmental performance are, in general, more competitive because 
INTERNATIONAL JOURNAL OF ACADEMIC RESEARCH IN BUSINESS AND SOCIAL SCIENCES

Vol. 10, No. 8, August, 2020, E-ISSN: 2222-6990 @ 2020 HRMARS

environmental management positively influences operational performance. Moreover, Mani et al. (2017) report that improvement in working conditions in organisations will benefit the buyer's operational performance by way of accident reduction, fewer disruptions, and increases in product delivery time. This view is shared by Pagell et al. (2010) who opine that better working conditions for employees is one sure way of improving product quality which is due to the employees' enhanced motivation. Finally, Yang et al. (2011) reveal in their study, a significantly positive association between advanced operations management systems and mass operational and lean operational performance.

However, researchers such as Cheu et al. (2017) maintain that previous empirical investigations have largely reported of mixed and inconsistent results which indicate trade-offs or some degree of ambiguity between EMP and OP. For instance, empirical findings from the studies carried out by Nishant et al., (2015) indicated that reducing emissions and purchasing green power contributes to the improvement in operational performance. Furthermore, Jabbour et al., (2015) discovered, from his study, a consistently positive and significant impact of environmental management on operational performance of companies whilst Das (2018) found no significant relationship between the two in a similar investigation. As a result, a recommendation was made by Cheu et al., (2017) for future research to verify the relationship from the hypotheses building stage in combination with other variables since their study failed to fully define it. The current study is inspired by findings from Cheu et al. (2017); Das (2018).

\section{Expected Findings}

The study is designed to offer theoretical confirmation to a plethora of existing inconclusive findings in the sustainability scholarship that, invariably, gravitate towards the assertion that the adoption of sustainable supply chain management practices by firms, especially manufacturing firms, does not automatically engender solid operational performance. The general import of such established finding is that the relationship between SSCM practices and operational performance is non-linear and will require an intervening variable such as organisational innovation to amplify the desired impact of the former on the latter. Such finding, if confirmed by the study, will offer a useful guidance to supply chain pundits, academicians and industry practitioners and will, above all, extend existing knowledge in the sustainability scholarship on the subject.

\section{Conclusion}

The impact of the institutional theory on the influence of innovation in SSCM adoption and operational performance can only be validated through empirical testing. As a result, a study is about to be conducted to determine the mediating influence of organisational innovation in the relationship between sustainable supply chain management practices and operational performance targeting 310 manufacturing companies in Ghana. The study is at the stage of data collection and the findings will be duly documented and reported on. It is anticipated that the findings arising of the study will bear significance for researchers and practitioners alike. The study is, primarily, designed to address the apparent lack of theoretical justification to explicate the relationship amongst the trio variables: sustainable supply chain management practices, organisational innovation and operational performance and also to ramp up the current level of awareness and the practical necessity associated with adoption and implementation of sustainability initiatives especially among manufacturing firms. In the final analysis, manufacturing organisations will be better equipped with 
INTERNATIONAL JOURNAL OF ACADEMIC RESEARCH IN BUSINESS AND SOCIAL SCIENCES Vol. 10, No. 8, August, 2020, E-ISSN: 2222-6990 @ 2020 HRMARS

the needed skill-set and acumen to increase their profitability levels and undertake practices that are pro-environmentally.

\section{References}

Aguilera-Caracuel, J., \& Ortiz-de-Mandojana, N. (2013). Green innovation and financial performance: an institutional approach. Organization \& Environment, 26(4), 365-385.

Ahmed, W., Najmi, A., \& Khan, F. (2019). Examining the impact of institutional pressures and green supply chain management practices on firm performance. Management of Environmental Quality: An International Journal, 1477-7835.

Ahmed, W., Najmi, A., Arif, M., \& Younus, M. (2019). “Exploring firm performance by institutional pressures driven green supply chain management practices". Smart and Sustainable Built Environment, 8(5), 415-437.

Ahmed, W., Ahmed, W., \& Najmi, A. (2018). “Developing and analyzing framework for understanding the effects of GSCM on green and economic performance: perspective of a developing country". Management of Environmental Quality: An International Journal, 29(4), 740-758.

Bag, S., Gupta, S., \& Telukdarie, A. (2018). Importance of innovation and flexibility in configuring supply network sustainability. Benchmarking: An International Journal, 25(9), 2018, 3951-3985.

Baird, K., Jia Hu, K., \& Reeve, R. (2011). "The relationships between organizational culture, total quality management practices and operational performance". International Journal of Operations and Production Management, 31(7), 789-814.

Bastas, A., \& Liyanage, K. (2018). Sustainable supply chain quality management: A systematic review. J. Clean. Prod. 181, 726-744.

Bastas, A., \& Liyanage, K. (2018). Integrated quality and Supply Chain Management Business Diagostic for Organisational sustainability Improvement: Sustainable production and Consumption, 17(2019), 11-30

Bocken, N. (2017). "Business-led sustainable consumption initiatives: impacts and lessons learned", Journal of Management Development, 36 (1), 81-96.

Callado, A. L. C. (2010). Modelo de mensuração de sustentabilidade empresarial: uma aplicação em vinícolas localizadas na Serra Gaúcha. PhD Dissertation, Federal University of Rio Grande do Sul, Porto Alegre.

Carter, C. R. (2005). "Purchasing social responsibility and firm performance: the key mediating roles of organizational learning and supplier performance". International Journal of Physical Distribution \& Logistics Management, 35(3), 177-94.

Carter, C., R., \& Easton, P. L. (2011). Sustainable supply chain management: evolution and future directions. Int. J. Phys. Distrib. Logist. Manag. 41 (1), 46-62.

Carter, C., R., \& Rogers, D. S. (2008). A framework of sustainable supply chain management: moving toward new theory. Int. J. Phys. Distrib, Losgist. Manag. 38(5), 360-387.

Chu, H., S., Yang, H., Lee, M., \& Park, S. (2017). The Impact of Institutional Pressures on Green Supply Chain Management and Firm Performance: Top Management Roles and Social Capital. Sustainability. 2017(9), 764.

Chu, M., Shahmehr, F., \& Khosla, R. (2017). "Dynamic capabilities in aged care service 
INTERNATIONAL JOURNAL OF ACADEMIC RESEARCH IN BUSINESS AND SOCIAL SCIENCES Vol. 10, No. 8, August, 2020, E-ISSN: 2222-6990 @ 2020 HRMARS

innovation: the role of social assistive technologies and consumer-directed care strategy", Journal of Services Marketing, 31 (7), 745-759.

Christmann, P. (2000). Effects of "best practices" of environmental management on cost advantage: the role of complementary assets. Acad. Manage. J. 43, 663-680.

Daft, R., L., \& Marcic, D. (2004). Understanding management, Versailles: Thomson South-Western.

Dam, L., \& Petkova, B. N. (2014). The impact of environmental supply chain sustainability programs on shareholder wealth. International Journal of Operations \& Management. 34(5) 586-609.

Das, D. (2018). Development and validation of a scale for measuring sustainable supply chain management practices and performance. J. Clean. Prod. 164, 1344-1362.

Dimaggio, P., J., Powell, W.W. (1983). The iron cage revisited: Institutional isomorphism and collective rationality in organisational fields. Am. Social. Rev., 48, 147-160.

Dyck, B., \& Silvestre, D. S. (2018). Enhancing socio-ecological value creation through sustainable innovation 2.0: moving away from maximizing financial value capture. Journal of Cleaner Production, 171(1), 1593-1604.

Elkington, J. (2004). Enter the triple bottom line. In: Henriques, A., Richardson, J. (Eds.), The Triple Bottom Line: Does it All Add up? Earthscan, London. 1-16.

Fettermann, D., Cavalcante, C., Almeida, T., \& Tortorella, G. (2018). "How does Industry 4.0 contribute to operations management?" Journal of Industrial and Production Engineering, 35(4), 255-268.

Grewal, R., \& Dharwadkar, R. (2002). "The role of the institutional environment in marketing channels", Journal of Marketing, 66 (3), 82-97.

Gualandris, J., \& Kalchschmidt, M. (2014). Customer pressure and innovativeness: Their role in sustainable supply chain management. J. Purch. Supply Manag. 20, 92-103.

Hart, S. L. (1995). "A natural-resource-based view of the firm", Academy of Management Review, 20 (4), 986-1014.

Hayagreeva, R., \& Sivakumar, K. (1999). “Institutional sources of boundary-spanning structures: the establishment of investor relations departments in the fortune 500 industrials", Organization Science, 10 (1), 27-42.

Hult, G., T., M., Ketchen, D., J., Cavusgil, S., T., \& Calantone, R. J. (2006). “Knowledge as a strategic resource in supply chains". Journal of Operations Management, 24(5), 458-75.

Hutchins, M., J., \& Sutherland, J.W. (2008). An exploration of measures of social sustainability and their application to supply chain decisions. J. Clean. Prod. 16 (15), 1688-1698.

Jabbour, C., J., C., Jugend, D., de Sousa Jabbour, A., B., L., Gunasekaran, A., \& Latan, H. (2015). Green product development and performance of Brazilian firms: measuring the role of human and technical aspects. Journal of Cleaner Production, 87, 442-451.

Jajja, M., S., S., Asif, M., Montabon, F., L., \& Chatha, K. A. (2018). "The influence of institutional pressures and organization culture on Supplier Social Compliance Management Systems", International Journal of Physical Distribution \& Logistics Management.

Jia, F., Zuluaga-Cardona, L., Bailey, A., \& Rueda, X. (2018). Sustainable supply chain management in developing countries: An analysis of the literature. Journal of Cleaner Production 189 (2018) 263-278.

Kavigtha, M. K. (2017). Influence of Sustainable Logistics Practices Transport Performance 
INTERNATIONAL JOURNAL OF ACADEMIC RESEARCH IN BUSINESS AND SOCIAL SCIENCES

Vol. 10, No. 8, August, 2020, E-ISSN: 2222-6990 @ 2020 HRMARS

of Transport Service Providers in Malaysia. Thesis.

Kennerley, M., \& Neely, A. (2002). A framework of the factors affecting the evolution of performance measurement systems. International Journal of Operations \& Production Management, 22(11), 1222-1245.

Klassen, R., D., and Vereecke, A. (2012). Social issues in supply chains capabilities link responsibilities risk (opportunity) and performance. International Journal of Production Economics, 140(1), 103-115.

Kleindorfer, P., R., Singhal, K., \& Wassenshove, L. N. V. (2005). Sustainable operations management. Prod. Oper. Manag. 14(4), 482-492.

Kneipp, J., M., Gomes, C., M., Bichueti, R., S., Frizzo, K., \& Perlin, A. P. (2019).

Sustainable innovation practices and their relationship with the performance of industrial companies. Revista de Gestão, 26(2), 2019, 94-111.

Liao, S., \& Chu, H. (2013), "Influence of consumer online resale awareness on purchase decisions: a mental accounting perspective", European Journal of Marketing, 47(10), 15761597.

Lu, R., X., A., Lee, P., K., C., \& Cheng, T.C.E. (2012). Socially responsible supplier development: construct development and measurement validation. Int. J. Prod. Econ. 140 (1), 160-167.

Marshall, D., McCarthy, L., Heavey, C., \& McGrath, P. (2014). Environmental and social supply chain management sustainability practices: construct development and measurement. Prod. Plann. Contr. 26(8), 673-690.

Marshall, D., McCarthy, L., Heavey, C., \& McGrath, P. (2015). Environmental and social supply chain management sustainability practices: Construct development and measurement. Prod. Plan. Control, 26, 673-690.

Meyer, J., W., \& Rowan, B. (1977). "Institutionalized organizations: formal structure as myth and ceremony", American Journal of Sociology, 83(2), 340-363.

Mitra, S., \& Datta, P. P. (2014). Adoption of green supply chain management practices and their impact on performance: an exploratory study of Indian manufacturing 52(7), 2085-2107

Mollenkopf, D., Closs, D., Twede, D., Lee, S., \& Burgess, G. (2005). “Assessing the viability of reusable packaging: a relative cost approach", Journal of Business Logistics, 26(1), 169-97.

Neely, A., Adams, C., \& Kennerley, M. (2002). The performance prism: the scorecard for measuring and managing business success. London, UK: Prentice Hall.

Nidumolu, R., Prahalad, C., K., \& Rangaswami, M. R. (2009). Why sustainability is now the key driver of innovation. Harvard Business Review, 87(9), 56-64.

Nishant, R., Teo, T., S., H., \& Goh, M. (2015). Are There Limits to the EmissionsOperational Performance Linkage? Acad. Manag. Proc., 1, 16470.

Pagell, M., \& Wu, Z. (2009). Building a more complete theory of sustainable supply chain management using case studies of 10 exemplars. J. Supply Chain Manage. 45 (2), 37-56.

Pazirandeh, A., \& Jafari, H. (2013). Making sense of green Logistics. International Journal Productivity and Performance Management, 62(8), 889904.

Perez-Aleman, P., \& Sandilands, M. (2008). Building value at the top and the bottom of the global supply chain: MNC-NGO partnerships. Calif. Manag. Rev. 51(1), 24-49.

Perez-Aleman, P. (2011). "Collective learning in global diffusion: spreading quality standards in a developing country cluster", Organization Science, 22(1), 173-189.

Porteous, A., H., Rammohan, S., V., \& Lee, H. L. (2015). “Carrots or sticks? Improving 
INTERNATIONAL JOURNAL OF ACADEMIC RESEARCH IN BUSINESS AND SOCIAL SCIENCES Vol. 10, No. 8, August, 2020, E-ISSN: 2222-6990 @ 2020 HRMARS

social and environmental compliance at suppliers through incentives and penalties". Production and Operations Management, 24(9), 1402-1413.

Porter, M., E., \& Kramer, M. R. (2002). "The competitive advantage of corporate philanthropy", Harvard Business Review, 80(12), 56-68.

Porter, M., E., \& van der Linde, C. (1995). Green and competitive: ending the stalemate. Harv, Bus. Rev., 73-120-133

Rossini, M., Costa, F., Tortorella, G., L., \& Portioli-Staudacher, A. (2019). "The interrelation between Industry 4.0 and lean production: an empirical study on European manufacturers". The International Journal of Advanced Manufacturing Technology, 102(912), 3963-3976.

Rosenau, W., V., Twede, D., Mazzeo, M., A., \& Singh, S. P. (1996). "Returnable/reusable logistical packaging: a capital budgeting investment decision framework". Journal of Business Logistics, 17(2), 139-65.

Roy, S., Sivakumar, K., \& Wilkinson, I. F. (2004). "Innovation generation in supply chain relationships: a conceptual model and research propositions". Journal of Academy of Marketing Science, 32(1), 61-79.

Saleh, R., A., Sweis, R., J., \& Saleh, F. I. M. (2018). Investigating the impact of hard total quality management practices on operational performance in manufacturing organizationsEvidence from Jordan. Benchmarking: An International Journal 25(7), 2018, 2040-2064.

Seuring, S., \& Müller, M. (2008). From a literature review to a conceptual framework for sustainable supply chain management. J. Clean. Prod. 16 (15), 1699-1710.

Srivastava, S. K. (2007). 'Green Supply-Chain Management: A State-of-the-Art Literature Review', International Journal of Management Reviews 9(1), 53-80.

Staw, B., M., \& Epstein, L. D. (2000). "What bandwagons bring: effects of popular management techniques on corporate performance, reputation, and CEO pay". Administrative Science Quarterly, 45(3), 523-556.

Terziovski, M., \& Samson, D. (1999). "The relationship between total quality management practices and operational performance". Journal of Operations Management, 17(4), 393409.

Thompson, V. A. (1965). Bureaucracy and Innovation. Admin. Sci. Q 5, 1-20

Toffel, M., W., Short, J., L., \& Ouellet, M. (2015). "Codes in context: how states, markets, and civil society shape adherence to global labor standards". Regulation \& Governance, 9(3), 205-223.

Tortorella, G., L., Giglio R., \& Van Dunn, D. H. (2019). Industry 4.0 Adoption as a Moderator of the Impact of Lean Production Practices on Operational Performance Improvement: International Journal of Operations \& Production Management, 0144-3577.

Tortorella, G., L., Fettermann, D., Frank, A., G., \& Marodin, G. A. (2018). “Lean manufacturing implementation: leadership styles and contextual variables". International Journal of Operations \& Production Management, 38(5), 1205-1227.

Villas Bôas, H. C. (2011). A indústria extrativa mineral e a transição para o desenvolvimento Sustentável. CETEM/MCT/CNPq, Rio de Janeiro.

Walley, N., \& Whitehead, B. (1994). "It's not easy being green". Harvard Business Review, 72(3), 46-52.

Welford, R., \& Frost, S. (2006). Corporate social responsibility in Asian supply chains. Corp. 
INTERNATIONAL JOURNAL OF ACADEMIC RESEARCH IN BUSINESS AND SOCIAL SCIENCES

Vol. 10, No. 8, August, 2020, E-ISSN: 2222-6990 @ 2020 HRMARS

Soc. Responsib. Environ. Manag. 13(3), 166-176.

Winter, M., \& Knemeyer, A. M. (2013). Exploring the integration of sustainability and supply chain management. Int. J. Phys. Distrib. Logist. Manag. 43(1), 18-38.

World Commission on Environment and Development (WCED) (1987). Our Common Future Commission on Environment and Development (WCED). Future. Oxford University Press, Oxford and New York.

Yang, M., G., Hong, P., \& Modi, S.M. (2011). Impact of lean manufacturing and environmental management on business performance: an empirical study of manufacturing firms. Int. J. Prod. Econ. 129(2), 251-261.

Yang, M. G. (2013). Developing a Focal Firm's Sustainability Chain Framework: ProQuest No.10631395, LLC-2017.

Zhu, Q., Liu, J., \& Lai, K. H. (2016). Corporate social responsibility practices and performance improvement among Chinese national state-owned enterprises. Int. J. Prod. Econ. 171 (Part 3), 417-426 